\title{
Early Childhood Pedagogy in a Socio-cultural Medley in Ghana: Case Studies in Kindergarten
}

\section{Mumuni Thompson ${ }^{1}$}

Published online: 6 July 2019

(c) The Author(s) 2019

\begin{abstract}
In the quest for quality in early childhood education, it is important to explore the subtleties that define socio-culturally relevant pedagogy. A qualitative, multi-case study approach was used to explore perspectives of teachers about socio-cultural influences on their teaching in kindergarten classrooms in Ghana. Four teachers from two kindergartens participated in the research. Data were collected across a six-month period and were drawn from semi-structured individual interviews, paired-teacher interviews, and field notes made during classrooms observations. Both within-case and cross-case analyses were used to explore how the local sociocultural context influenced the use of learning materials, storytelling, and use of traditional songs and rhymes. Teachers believed that adapting their practices to the socio-cultural context could support children's understanding of cognitive concepts, language, literacy and moral development. The findings provide evidence about how individual teachers take account of the socio-cultural contexts in their pedagogy. The findings demonstrated that the teachers had sufficient agency to modify and adapt their pedagogies that took account of the social-cultural experiences of children and applied these ideas within the curriculum framework in order to support children's learning.
\end{abstract}

Keywords Early childhood pedagogy $\cdot$ Socio-cultural contexts $\cdot$ Children's learning $\cdot$ Ghana $\cdot$ Kindergarten

\section{Résumé}

Dans la quête de la qualité en éducation de la petite enfance, il est important de sonder les subtilités définissant une pédagogie pertinente au plan socioculturel. Une approche de recherche qualitative avec étude de cas multiples a servi à explorer les points de vue des enseignants à propos des influences socioculturelles sur leur enseignement dans des classes maternelles du Ghana. Quatre enseignants de deux ma-

Mumuni Thompson

tmumuni@ucc.edu.gh

1 Department of Basic Education, College of Education Studies, Faculty of Educational Foundations, University of Cape Coast, Cape Coast, Ghana 
ternelles ont participé à cette recherche. Les données ont été collectées sur une période de six mois et ont été tirées d'entretiens individuels semi structurés, d'entretiens d'enseignants jumelés, et de notes de terrain prises pendant les observations des classes. Des analyses cas par cas et entre cas ont servi à explorer la façon dont les contextes socioculturels locaux influencent l'utilisation du matériel pédagogique, d'histoires à raconter, de chants et de comptines traditionnels. Les enseignants adaptaient leurs pratiques au contexte socioculturel pour soutenir les enfants dans la compréhension de concepts cognitifs, le langage, l'alphabétisation et le développement moral. Les résultats apportent des connaissances sur la façon dont les enseignants en tant qu'individus tiennent compte d'influences socioculturelles dans leurs pratiques. Ces résultats démontrent que les enseignants ont une capacité d'agir suffisante pour modifier et adapter leurs pratiques afin de prendre en considération les expériences socioculturelles des enfants et appliquer leurs idées dans le cadre du programme scolaire pour soutenir l'apprentissage des enfants.

\section{Resumen}

En la búsqueda de calidad en la educación infantil temprana, es importante explorar los diferentes matices que definen la enseñanza con énfasis sociocultural. Un estudio cualitativo de casos múltiples se llevó a cabo con el fin de explorar las perspectivas de docentes sobre las influencias socioculturales en su práctica pedagógica en salones de kindergarten en Gana. En este estudio participaron cuatro docentes de dos salones de kindergarten. Se recolectaron datos durante un período de seis meses por medio de entrevistas individuales semiestructuradas, entrevistas pareadas con docentes, y notas de campo tomadas durante observaciones en el salón de clase. Se realizaron análisis individuales de cada caso y generales de todos los casos para explorar la forma en que los contextos socioculturales influenciaron el uso de materiales pedagógicos, historias, canciones y rimas tradicionales. Los docentes adaptaron sus prácticas pedagógicas al contexto sociocultural para ayudar a los niños a comprender conceptos cognitivos, lenguaje, lectura y escritura, y desarrollo moral. Los resultados comprobaron que cada docente tiene en cuenta las influencias socioculturales en sus prácticas pedagógicas. Estos hallazgos demostraron que los docentes tienen suficiente autonomía como agentes para modificar y adaptar sus prácticas y así incorporar las experiencias socioculturales de los niños y poner en práctica sus ideas dentro del currículo para apoyar el aprendizaje de sus estudiantes.

\section{Introduction}

Instructional practices in early childhood education are informed by a range of educational and developmental theories. Developmentally appropriate pedagogy is anchored in the provision of constructivist and culturally situated learning experiences for children (Bredekamp and Copple 2007). Research evidence has suggested that children's development is largely influenced by processes of cognitive construction when learners are actively engaged (Piaget 1952; Vygotsky 1978). Instructional processes that are child-centred and driven by an 
instructional approach that sees the child as a complex being with rich and unique potential enable the differential learning needs of children to be accommodated. However, there has been little research that has explored early childhood pedagogy and its attendant contributions to children's development within the WestAfrican sub-region. There is an incomplete picture regarding how early childhood pedagogy influences children's development in early childhood settings in West Africa. This research employs a qualitative case study approach to explore how children's socio-cultural contexts influence teachers' practices in kindergarten classrooms in Ghana.

While wide-ranging academic research has investigated the influence of early childhood pedagogy as a significant driver of children's development (Farquhar and White 2014; Hedges and Cullen 2012; Murray 2014), much less research has explored early childhood pedagogy within the West-African sub-region and studies focused on differing socio-cultural contexts are silent, regarding the extent to which children's socio-cultural settings influence selection of pedagogy. Teachers are expected to be reflective practitioners by applying their knowledge and understandings of instructional practices to resolve the challenges that they encounter in their classrooms. Children also require appropriate responses from teachers, based on teachers' knowledge and understandings of the developmental needs of individual children. Teaching and learning processes are dependent on teacher's insights, regarding children's learning needs (Siraj-Blatchford et al. 2002). These insights provide early childhood educators with nuanced understandings to inform their choices for effective pedagogy that is in synchrony with the children in their classroom and how they learn. Child-friendly pedagogies help children to accomplish tasks through collaborative efforts. The findings from this research can provide early childhood teachers, researchers, and other stakeholders (e.g. curriculum developers) with insights about how socio-cultural contexts influence pedagogy.

The ecological theory of Bronfenbrenner (1979) framed the current study. This theory provides understanding about how interactions between a child and his/her socio-cultural context serve as basis for human development. The theory considers the emerging relations between the developing child and the child's experiences with others in their socio-cultural context. Structures closest to the child, such as family and schools, are important, and a synergy is forged between socialising agents, including teachers, to enhance and promote children's development in diverse ways. The ecological milieu is seen as a layer with attendant diverse structures. Through adult support, children apply socio-cultural tools through their language and literacy skills to make meaning of their everyday experiences within classrooms. In kindergarten, instructional processes are often defined by culturally situated practices. Early childhood pedagogy is largely informed by context-specific learning materials, storytelling, singing and rhymes to help engage children in learning through new experiences which promote development.

Children's development is influenced not only by socio-cultural contexts (Rogoff, 2003) but also by best practices in early childhood pedagogy drawn from knowledge in other socio-cultural contexts internationally. Early childhood teachers can promote children's holistic development in diverse ways by drawing on essential quality features of kindergarten education as practised across the world (Harris 2015). 


\section{Research Context}

The 2007 education reforms in Ghana marked a watershed regarding early childhood education because this government-led policy initiative had a twofold impact on early childhood education delivery in the country: First, the kindergarten aspect of early childhood education became part and parcel of the formal schooling system leading to the development of the early childhood curriculum. Second, the policy brought about the introduction of degree and diploma programmes in early childhood education, within some of the universities in Ghana, for the purpose of educating teachers in the content and pedagogy to improve teachers' practices in kindergarten classrooms (Amadahe 2008).

The reforms encouraged the crafting of a philosophy of education for early childhood education that is based on socio-cultural influences such as traditional knowledge, indigenous pedagogy such as such as storytelling, traditional songs, traditional rhymes, and proverbs, values, and attitudes as well as the exigencies of the global context. It emphasises the development of well-balanced individuals and the need for effective teacher practices to promote the holistic development of young children (Ministry of Education 2007).

The early childhood programmes in Ghana are organised along the following lines: Crèche (0-1 years); Day care (1-2 years); Nursery (2-3 years); and Kindergarten (4-5 years) (Ministry of Education 2007). However, initially, only the kindergarten component of early childhood education was incorporated into the formal schooling system in the country. Hence, other aspects of the early childhood programme fall under the auspices of the private sector. Since the private sector in early childhood education is not well regulated, different curricular models such as Montessori and Reggio Emilia inform teachers' practices (Deku 2010). However, within the public school kindergarten system, Developmentally Appropriate Practice (DAP) consistently influences teaching and learning in kindergarten classrooms. In the latter part of 2014, the Ministry of Education incorporated the nursery component of early childhood education into the basic public school system. DAP now also influences teacher practices in nursery classrooms.

\section{Mother-Tongue Instruction and Bilingual Education}

Rosekrans et al. (2012) noted that there have been several large-scale attempts in the past to introduce mother tongue as the medium of instruction in Ghana (e.g. in non-formal education and shepherd schools). Earlier attempts did not prove successful because of financial constraints and the lack of political will. While Hornberger (2009) noted that "Opening up spaces for multilingual education is like considering all languages in the ecology and recognising that these languages are situated in spaces and contexts" (p. 6). In the light of this assertion and through international pressure and donor support, the decision was made by the Government of Ghana to introduce bilingual education nationwide. The language policy which is currently implemented in Ghana is referred to as the National Literacy Acceleration Programme (NALAP). The policy is under the auspices of the Ghana Education Service, a sector under the Ministry of Education. 
According to Rosekrans et al. (2012) and the Ministry of Education (2013), the NALAP is a bilingual medium of instruction that is designed to guide mothertongue instruction as well as the transition of children to the English language. This policy also outlines that children from Kindergarten up to Grade 3 of primary school should receive instruction in their language and literacy courses in their mother tongue and also in English at the same time. Children are expected to spend 5 years of their education learning in their mother tongue (L1). Kindergarten children and children in primary school are expected to spend $90 \%$ and $70 \%$, respectively, of their time learning in their first language, (L1), while the balance of their time (10\% and $30 \%$ ) is spent learning in the English language. Over time, it is expected that children gradually spend more time learning in the English language and this should increase until parity is achieved between the time spent learning in first language (L1) and in the English language.

\section{Methodology}

A multi-case, qualitative research approach was used in this study to understand the similarities and differences regarding kindergarten teachers' practices in Ghana and the influences of different socio-economic contexts. The current article is an extract from the author's PhD dissertation which was planned and carried out by the author with advice from a supervisory committee. The research received approval from the University of British Columbia's (UBC) Behavioural Ethics and Research Board (Ethics certificate number: H15-00364). Data were collected in the two case-study schools from May 2015 to November 2015.

\section{Participants}

This analyses reported in this study involved four participants from two schools, Tata School and Kariba School, Kate and Sophia were teachers from Tata School which is located in an urban area within the Cape Coast Metropolis of Ghana, while Ramatu and Akotia were from Kariba School which is located in a rural area within the Cape Coast Metropolis of Ghana. Kate had been a teacher for 25 years, while Sophia has taught for 19 years. Ramatu has been a teacher for 9 years, and Akotia has taught for 7 years. Kate and Sophia held Bachelor degrees in Early Childhood Education, and Ramatu and Akotia held Diplomas in Early Childhood Education.

\section{Data Collection}

Data were gathered through semi-structured interviews with each teacher and through observations in their classrooms. The participants were interviewed in pairs on one occasion and individually on two occasions. Interviewing teachers in pairs provided a platform for them to share their rich experiences with each other and the researcher. Interviewing the participants on multiple occasions also allowed the author-researcher to identify consistencies in the responses of the participants across 
interview sessions. The multiple interviews allowed the teachers to talk at length and elaborate on their beliefs and practices because they were given opportunities to react to similar questions on multiple occasions. The interviews were conducted when children were on break. Each visit to the classrooms usually lasted $1 \mathrm{~h}$.

Four processes were used to ensure the trustworthiness of the research and data analysis that included: use of diverse data sources (triangulation); participant and researcher debriefings; member-checking by the participants of the data; and recording and transcription of data that enabled thick description of the data to be generated for analyses. The semi-structured interviews included questions about how early childhood educators make learning in classrooms meaningful and relevant to young children. Important questions that related to the content reported in these analyses included whether teachers' practices in kindergarten classrooms were developmentally appropriate and how their practices were culturally responsive. After the transcriptions of the interviews, the teachers were given opportunities to cross-check whether the transcripts reflected their views.

In the second phase of the research, observations took place in all kindergarten classrooms. The observations provided an opportunity for the researchers to determine how teachers' knowledge unfolded in real-life classroom contexts. During the observations in an unobtrusive manner, I conversed with the kindergarten teachers, while the children were engaged in small group or individual activities in order to seek clarifications on the teachers' reasons for engaging children in various kinds of activities. Interactions with the teachers at the end of each observation period for about $10 \mathrm{~min}$ also enabled me to seek clarifications about practices. These observational opportunities enabled me to clarify my understandings of the issues arising from the observations of teachers' instructional practices in the classrooms. For example, when teachers were seen moving from one group to another giving guidance to the different children on how to accomplish a task or whenever a child appeared to encounter a challenge.

Field notes were made in the observation sessions rather than using audio- or video-recording. This reduced the intrusiveness of the researcher in the classroom. The observations allowed me to unpack issues beyond teachers' self-reports of practices as teachers describe their specific actions and reasons for their actions within real-life teaching and learning contexts. The observations of teachers were also completed after the teacher interviews. Apart from been a technique for generating primary data, these observations also serve as a validation check on the interview data.

\section{Results}

The qualitative data analyses were conducted on a case by case basis to enable the identification of key categories and themes for each teacher to be identified. Initially, teachers' ideas expressed in the interviews were organised into categories and then into themes, described as patterns in the data and descriptions of phenomenon under investigation (Boeije 2010). The themes generated from the interview analyses were also validated from the observational data. 
In this section, the case study of the two teachers at Tata School which was located in an urbane district is first reported. This is followed by the analyses of the data from the case study of the two teachers at the Kariba School located in a rural district.

\section{The Kindergarten Teachers at Tata School}

At Tata School, the two kindergarten teachers discussed key features of their early childhood pedagogy with a focus on learning materials used, and how stories and traditional songs were a means of situating children's learning within the socio-cultural context of the children's direct experiences at home and school.

\section{Making Learning Meaningful Through Specific Learning Materials}

The teachers, Kate and Sophia, revealed how children's family backgrounds guided their selection of learning materials. For example, they explained the need to translate materials such as conversational posters or environmental print into the language that children used at home.

Kate: I consider their background, and [if] their background is English. So, it becomes the basis for selecting learning materials. For instance, if I'm teaching the speaking and listening aspects of literacy, I use NALAP materials such as a conversational poster which is written in Fante language with pictures depicting activities within the local context. But whatever I do in class concerning the poster, I have to translate it into English language before they can understand what I am teaching.

Sophia: I use materials that can be found easily in the children's immediate environment. But I have to translate the materials which are in Fante into the English language before we can use them because the children see these materials in their environment but they do not know what they are. ... I have to translate from Fante language into the English language to help them understand the concepts better. But as time goes on, I use [both] the mother tongue and the English language to explain concepts.

Because their children did not understand the Fante language, these teachers saw the need to translate concepts contained from the Fante language into English. This allowed the children to extract more meaning from their learning experiences in class, even though the learning materials supplied with the curriculum were meant to align with the children's socio-cultural experiences. Kate and Sophia perceived that children's socio-cultural contexts should serve as a basis for the selection of learning materials. However, the teachers perceived the impact of these contexts on children's development differently. For Kate, “... It helps children understand their environment", while for Sophia, “... Children learn better if learning materials are selected from their immediate environment". 
Overall, these teachers considered that learning in kindergarten occurs when the teacher provides opportunities for children to build on what they already know from prior experiences in order to link new ideas with familiar experiences.

\section{Making Learning Meaningful Through Storytelling}

Both teachers, from Tata School, believed that storytelling was an effective means of making learning meaningful and relevant to children in kindergarten classrooms. For example, Kate indicated, “... Helps a child develop moral values which are acceptable to a child's social context". Sophia believed that storytelling, “... Helps pass on the norms of society to the younger ones".

Storytelling provided an opportunity for children to see themselves through others' experiences by relating to characters in the story and commenting on the characters' essential life experiences in relation to accepted local norms of society. However, the teachers saw the means of interpreting and applying storytelling in kindergarten classrooms differently.

Kate: I show them pictures for them to tell me the moral lesson connected to a particular episode in the story. If it is about unacceptable conduct, such as a character using the left hand to collect something or greet someone, I ask the children to comment on the behaviour of the character.

Sophia: If the story is about 'Ananse and the wisdom pot,' some of the children would not know what an earthenware pot is because they come from different homes. So, to make the story meaningful to them, I usually bring a pot to class. And as I narrate the story, I let them look at the pot and say something about it, and then I relate it to the modern version of the cooking pot which is common in homes where the children are coming from.

For Kate, children understand concepts which are taught in class more effectively if the teacher provides explanations in such a way that there is a linkage between the concept and a corresponding experience that a child may have previously encountered. Thus, for storytelling to have the desired impact on children's development, the teacher incorporated familiar physical cultural objects to enhance and promote children's comprehension which, in turn, has an impact on children's moral development. Kate and Sophia also considered that a story could be meaningful to children if it is presented to them in inventive ways.

Kate: I dress and behave like the main character in the story and at every stage of the story.

Sophia: Storytelling helps the children to relate to their environment. For, example, one of the children might be sent to the market by someone to buy something, but in the market, the women will not be able to speak the English language with him or her. But the child might see certain things that he or she wants to buy but cannot communicate with those in the market. So, I introduce Fante names of certain objects found in their environment into the stories so, 
as they listen to the stories, the names of these objects would be emphasised to help them become functional in their environment.

Through imitation of the traits of characters in a story, Kate promoted the development of the children in her classroom. Sophia, on the other hand, enabled her monolingual children to relate with others in their community by explaining the English language version of certain concepts in the Fante language through stories, Thereby, enabling her kindergarteners to be exposed to the Fante language in order to increase their familiarity with the local language.

\section{Making Learning Meaningful Through Traditional Songs}

Kate and Sophia used traditional Ghanaian songs as tools for making learning meaningful in their kindergarten classrooms. While they agreed on the significance of songs to children's development, they disagreed on some specifics. For example, Kate and Sophia acknowledged the significant role that traditional songs played in the children's acquisition of sounds and letter names in the English language. However, only Kate related the use of traditional songs to supporting children's moral development.

Kate: It imparts moral values in young children. For example, there is a traditional song which goes like this: “... The young hawk's mother is dead but instead of finding work to do she goes about hunting for chickens." The meaning of the song is that if one does not work hard, one will end up [leading a wayward life]. To make the moral values of the song more meaningful to the children, I relate it to the everyday experiences of the children in a classroom setting by telling them that if they don't do their homework or assignment, it means that they do not want to move to the next level.

Finally, the observations revealed that these two teachers, Kate and Sophia, used traditional songs, as tools for integrating children's learning experiences across subject areas. The teachers incorporated traditional songs into play-based activities that had a bearing on a lesson taught in class. A song usually emphasised key issues that underpinned the lesson, and they sang a song, and the teacher and children danced to the rhythms of the song. By using traditional songs, such as "Sansakroma" (i.e. a song where the hawk's mother is dead, but instead of leading a useful life he is stealing), the teacher expects to promote the moral development of the children.

The evidence from this case study suggested that the socio-cultural context of children is a determinant of what teachers consider is appropriate for children to learn. However, there was some diversity in how each teacher approached using cultural tools to make learning relevant to the children in an urban kindergarten setting.

\section{The Kindergarten Teachers at Kariba School}

At Kariba School, the two kindergarten teachers described their early childhood practices in relation to learning materials, storytelling, traditional songs as well as 
rhymes as their means of situating learning within the socio-cultural contexts of their kindergarten classrooms.

\section{Making Learning Meaningful Through Specific Learning Materials}

Ramatu and Akotia believed that children's socio-cultural contexts were one consideration that guided their selection of learning materials for their children. They explained:

Ramatu: I normally consider children's background by selecting learning materials which are common in children's environment. For example, many of the children help their mothers to sell vegetables and other items at the market. If the topic is about subtraction, I relate it [to] a market scene where the children help their mothers sell different kinds of vegetables such as tomatoes and garden eggs...As they engage in these activities in the market settings; they can bring these experiences into the classroom context. And this helps them to understand concepts taught in class.

Akotia: I take into consideration the child's home environment because children learn better if learning materials used in class are familiar to them.

Both teachers relied on their prior knowledge about the children, in selecting learning materials which were familiar to the children.

\section{Making Learning Meaningful Through Storytelling}

The teachers from Kariba School perceived storytelling as a means of situating learning within the children's socio-cultural contexts, although they perceived its impact on children's development differently.

Ramatu: Storytelling helps to develop the retentive memory of children because as children listen to stories, they narrate it to others. And as they do that, at some point, they will be able to narrate the story exactly as they heard it. It also helps them to develop listening skills.

Akotia: I use storytelling to promote the moral development of children. In recent times, some parents have shirked their responsibility as agents of moral development. So, it is the duty of the school which is one of the social institutions for moral development of children to use storytelling as a means of instilling moral values. For example, after taking the children through a storyline using a conversational poster, I ask the children to assess the behaviours of the characters in the story to determine whether the actions and the reactions of the characters were right or wrong.

For Ramatu, storytelling supported children's cognitive development (i.e. the capacity to retain information) and listening skills. For Akotia, storytelling promoted children's moral development in kindergarten classrooms. 
However, Ramatu and Akotia believed that there are inventive ways of presenting a story to maximise its impact on children's development. For example, Ramatu believed that storytelling could have the desired impact on children's development if the storyline is captured in a visual form. She explained:

Ramatu: I normally select stories from 'the big book.' The book contains several traditional stories which are useful for children's moral development. The stories are in a pictorial form from one stage of the story to another. As I open the book, I ask them to describe the pictures and predict what is likely to happen in the next stage of the story [regarding the actions and inactions of characters in the story].

In a similar way, Akotia perceived that stories captured in the form of picture imagery were both effective and appropriate for children's development. She explained:

Akotia: In this school, we have 'the big book' which contains several traditional stories which are useful for developing certain values in children. The plot of the story is in a pictorial form with few inscriptions.

Ramatu and Akotia perceived that storytelling impacted children's moral development, especially, if the plot of the story is presented to children in a developmentally appropriate manner through visual materials.

\section{Making Learning Meaningful Through Traditional Songs}

Ramatu and Akotia from Kariba School also used traditional songs in promoting children's development in their kindergarten classroom. However, the teachers did so for different reasons.

Ramatu: I use traditional songs in class to help the children integrate their learning experiences because, at the end of every lesson, I select some key issues that I emphasise in the lesson and compose a song. As we sing the song, we emphasise these issues, we jump, dance and shake our bodies in line with the lyrics of the song.

Akotia: It helps in building a child's vocabulary because while singing, children role-play some of the words in the song and this helps promote the language development of the children.

Ramatu and Akotia perceived that storytelling impacted children's moral development, especially, if the plot of the story is presented to children in a developmentally appropriate manner through visuals.

For Ramatu, traditional songs was a nexus for the integration of children's learning experiences because they provided opportunities for children to use play-based activities to emphasise key concepts that characterised a particular lesson. However, Akotia believed that traditional songs promoted children's language development because it provided an opportunity for children to role-play 
certain words. These teachers also had different views regarding how traditional songs were effective for promoting children's development.

Ramatu: I think children are always eager to engage in activities which are of interest to them. So, I use traditional songs which are popular in the communities of the children. But I alter it a bit to suit the activity that we are doing in class to make the activity interesting so that I can get the children involved in what we are doing.

Akotia:... It should have an element of activity in it so that the child can do the practical aspect of it by acting out the meaning of the words emphasised in the song and once the child does this he or she will always remember.

For Ramatu, using traditional songs which were popular in the children's communities made the activities in class appealing to the children. However, Akotia perceived that traditional songs when acted out improved children's retention of the song. Thus, traditional songs appeared to play attitudinal and conceptual roles in pedagogy.

\section{Making Learning Meaningful Through Traditional Rhymes}

Teachers at Kariba School used traditional rhymes as means of interpreting and applying developmental appropriate practice in their kindergarten classroom. However, Ramatu, and Akotia, spoke of varied reasons as to why this practice impacted children's development.

Ramatu: I use traditional rhymes a lot in this class because it makes lessons interesting to the children. It also gives them the opportunity to engage in activities which help them to understand what they are saying and what we are learning in class.

Akotia: In this class, we do subject teaching, but I use rhymes sometimes at the end of every lesson to help the children integrate their learning experiences. The children learn better when I use this approach.

For Ramatu, a rhyme was an effective means of promoting children's development in kindergarten settings because it aroused children's interest in a lesson and provided an opportunity for children to engage in activities to promote their understanding of concepts taught in class. For Akotia, a rhyme promoted children's understanding of concepts taught in class. Regardless, both teachers believed that rhymes could have such desired effects on children's development, only if they aligned with the social context of children.

Ramatu: Most of the rhymes we recite in the class have an English origin, so I usually introduce certain cultural elements which are familiar to the children into the rhyme to enable them to understand what they are saying. 
Akotia: For me to help children understand what they are saying in class and their environment. So, all the things mentioned in the rhyme should be things they see every day in their environment.

For both Ramatu and Akotia, rhymes that children recited in a kindergarten classroom could only have the desired impact on children's learning if socio-cultural elements within children's immediate environment were integrated into the learning experiences. They perceived that the impact of such rhymes on children's development was twofold: First, it helped children to better understand concepts taught in class, and second, it helped them understand their own world (i.e. "sasa").

\section{Discussion}

The qualitative data from the two case studies suggested that the socio-cultural context of children is an importance determinant in these teachers' beliefs about what is appropriate for children to learn in kindergarten. However, there was some diversity in how each teacher understood the integrations of socio-cultural materials into the learning experiences for children within, and across, the urban and rural kindergarten settings. Most themes were shared by all four teachers in the study, regardless of the school setting in which they taught. The participants from Tata School, Kate and Sophia, as well as Akotia from Kariba School, valued storytelling because of its impact on children's moral developments, whereas Ramatu at Kariba School perceived storytelling as a tool for the development of children's retentive memory and listening skills.

The participants had different specific reasons for valuing traditional songs, but regardless of the context (Tata School or Kariba School), the participants saw traditional songs as important. However, it appears that for teachers in an urban setting (Tata School), traditional songs provided a context to support children's language learning. Teachers in the rural setting (Kariba School) appeared to view traditional songs as a means to integrate children's learning with their other life experiences. It, therefore, appears that traditional songs could have a twofold impact on children's learning. Interestingly, teachers at Kariba School spoke of traditional rhymes separately from songs, although they believed that songs and rhymes could support children's learning in similar ways.

In a pluralistic religious society like Ghana, the issue of how to inculcate moral values in kindergarten settings has been a contested one for a very long time. Early childhood educators, and other stakeholders, have incorporated storytelling, as a pedagogical tool in the kindergarten curriculum of Ghana. Hunter and Elder (2010) noted that storytelling impacts on children's moral development and so early childhood educators have incorporated storytelling into their pedagogy. This is its important role as a cultural practice within traditional Ghanaian settings. Thus, it was not surprising that these teachers would identify storytelling as so important with a strong commitment held by some teachers (e.g. the teacher who dressed like one of the characters in the story). However, what was striking in the current study was that 
only one of the participants (e.g. Ramatu) pointed to the link between storytelling and children's cognitive development:

Storytelling helps to develop the retentive memory of children because as children listen to stories, they narrate it to others. And as they do that, at some point, they will be able to narrate the story exactly as they heard it.

The participants of the study agreed that traditional songs served as developmentally appropriate means of enhancing and promoting children's development in multiple ways. However, the developmental needs of their children determined how the teachers used the songs in kindergarten settings.

Traditional songs which included English language provided an opportunity for the teachers at Tata School to introduce the letter sounds of the English language to children, which, in turn, enhanced their pronunciations skills. In contrast, only the participants from Kariba School spoke of traditional rhymes as a means of promoting their children's development in diverse ways. Although the rhymes were also traditional English rhymes, these teachers perceived the rhymes as developmentally appropriate for integration into children's learning experiences, as well as a means of arousing children's interests in a learning activity. These teachers introduced culturally relevant elements into the rhymes (i.e. things seen every day in children's environments) to enhance the appropriateness of using rhymes.

By using materials readily available in both settings, these teachers tend to provide a familiar learning environment for their children which, in turn, further suggests that these teachers seemed to recognise at least, tacitly that "clear grounding in a location gives us the confidence to engage with knowledge from other locations as we deconstruct and reconstruct with our purposes" (Canagarajah 2005; p. 15). In addition to these materials being developmentally appropriate from a socio-cultural perspective, these teachers also revealed that they used learning materials that were familiar to the children to promote their understanding of their environment. Iyamu and Ogiegbaen (2007) proposed that it is detrimental to provide children with an education that has no bearing whatsoever on their daily lives or which does not enhance their understanding and engagement in their own environment. Thus, these teachers' use of context-appropriate materials in responsive ways with children, at the very least, promotes children's development. The use of familiar learning materials in the classrooms underscores these teachers' interpretation of Developmentally Appropriate Practice (DAP) on the importance of providing opportunities for children to engage in hands-on and physical activities in order to promote learning and development. Kamii and DeVries (1993) noted that young children are more mentally active when they are physically engaged in learning as they try to figure out how to accomplish any task.

\section{Conclusion}

The socio-cultural backgrounds of the children and their local contexts strongly influenced how early childhood pedagogy was implemented in these kindergarten classrooms in Ghana in order to promote language and literacy through specifically 
cultural relevant learning materials, traditional stories and songs. However, across the classrooms, there was diversity and difference in the different way that these materials and activities might be used and the nature of the learning that would result. The study's findings enhance our awareness of the richness of socio-cultural contexts and the curricular opportunities that can be drawn from this richness by teachers through which children make connections and construct meanings. This, in turn, can develop children's engagement in learning, as well as promoting creativity and problem-solving abilities. The study's findings reinforce the value of constructivist theories of learning that emphasise the importance of incorporating aspects and features of local socio-cultural contexts into the pedagogy. These findings illustrate how teachers connect children's learning experiences with local contexts in kindergarten classrooms in Ghana.

Acknowledgements I wish to acknowledge the support of my supervisors, Dr. Ann Anderson and Dr. Sampson Nashon, at the University of British Columbia, Vancouver, Canada, in completion of this research. I also wish to thank the participating teachers and schools for their contribution to this research.

Open Access This article is distributed under the terms of the Creative Commons Attribution 4.0 International License (http://creativecommons.org/licenses/by/4.0/), which permits unrestricted use, distribution, and reproduction in any medium, provided you give appropriate credit to the original author(s) and the source, provide a link to the Creative Commons license, and indicate if changes were made.

\section{References}

Amadahe, L. (2008). Assessment of the education reforms in Ghana. Journal of Education, 6(2), $25-54$. Boeije, H. R. (2010). Analysis in qualitative research. Thousand Oaks, CA: Sage Publications.

Bredekamp, S., \& Copple, L. (2007). Developmentally appropriate practices in early childhood programmes, serving children through age eight. Washington, D.C.: National Association for the Education of Young Children.

Bronfenbrenner, U. (1979). The ecology of human development. Cambridge, MA: Harvard University Press.

Canagarajah, A. S. (2005). Dilemmas in planning english/vernacular relations in post-colonial communities. Journal of Sociolinguistics, 9(3), 418-427.

Deku, K. (2010). Approaches to learning in kindergarten classrooms: A case of University of Cape Coast kindergarten teachers. Journal of Education, 15(6), 23-45.

Farquhar, S., \& White, E. J. (2014). Philosophy and pedagogy of early childhood: Educational Philosophy and Theory, 46(8), 821-832.

Harris, K. I. (2015). Developmentally universal practice: Visioning innovative early childhood pedagogy for meeting the needs of diverse learners. Early Child Development and Care, 185(11-12), 18801893. https://doi.org/10.1080/03004430.2015.1028395.

Hedges, H., \& Cullen, J. (2012). Participatory learning theories: A framework for early childhood pedagogy. Early Child Development and Care, 82(7), 921-940. https://doi.org/10.1080/03004 430.2011.597504.

Hornberger, N. H. (2009). Multicultural education policy and practice: Ten certainties (grounded in indigenous experiences). Language and Teaching, 12(4), 223-228.

Hunter, C., \& Elder, D. (2010). The role of storytelling in understanding children's moral/ethic decisionmaking. Multicultural Perspective, 12(4), 223-228.

Iyamu, F. O. S., \& Ogiegbaen, E. A. (2007). Parents and teachers' perception of mother-tongue medium of instruction in Nigeria primary school schools. Language, Culture and Curriculum, 83(1), $300-321$. 
Kamii, C., \& DeVries, R. (1993). Physical knowledge in preschool education: Implications for Piaget's theory. Washington, DC: National Association for the Education of Young Children.

Ministry of Education. (2007). Education reforms in Ghana. Guyana: Ministry of Education.

Ministry of Education. (2013). Education reforms in Ghana. Guyana: Ministry of Education.

Murray, J. (2014). Early childhood pedagogies. Spaces for young children to flourish. Early Child Development and Care, 185(11-12), 1715-1732.

Piaget, J. (1952). The origins of intelligence in children (translator - M. Cook, New York: International Universities Press. (Original work published 1936).

Rogoff, B. (2003). The cultural nature of human development. Oxford: Oxford University Press.

Rosekrans, K., Sherris, A., \& Chatry-Komarek, M. (2012). Education reforms for the expansion of mother-tongue education in Ghana. International Review of Education, 58(2), 595-618.

Siraj-Blatchford, I., Sylva, K., Muttock, S., Gilden, R., \& Bell, D. (2002). Researching effective pedagogy in the early years, (REPEY) Research Report 356. London: Department of Education and Skills.

Vygotsky, L. (1978). Mind and society: The development of higher psychological processes. London: Harvard University Press.

Publisher's Note Springer Nature remains neutral with regard to jurisdictional claims in published maps and institutional affiliations. 